\title{
Citrus Rust Mite Phyllocoptruta oleivora (Ashmead) (Arachnida: Acari: Eriophyidae) ${ }^{1}$
}

\author{
Emilie Demard and Jawwad A. Qureshi ${ }^{2}$
}

\section{Introduction}

The citrus rust mite, Phyllocoptruta oleivora (Ashmead), also called silver mite, is an important pest of citrus in most humid regions of the world (McCoy and Albrigo 1975, Vacante 2010) (Figure 1). It was first described in 1879 from Florida (Burditt et al. 1963). Phyllocoptruta oleivora is the most important mite pest of Florida citrus due to the cost of control and damage caused to fruits, particularly those for the fresh market (Knapp 1994, Hoy 2011). It coexists with another rust mite called the pink citrus rust mite, Aculops pelekassi (Keifer) (Childers and Achor 1999); however, Phyllocoptruta oleivora is usually the prevalent species.

\section{Distribution}

Phyllocoptruta oleivora is thought to have originated in Southeast Asia (Yothers and Mason 1930). It is a tropical species present in all citrus-growing areas of the world where humidity is high (Villanueva 2002, Hoy 2011). Regions where the mite represents a major pest of citrus include the Middle East (Georgia, Israel, and Turkey), South Africa, Australia, the USA, and southern Asia (Japan and China) (CIE 1970, Tropea Garzia and De Lillo 2018). In the United States, Phyllocoptruta oleivora is found throughout Florida and on the Coastal Intermediate region of California (Hoy 2011).

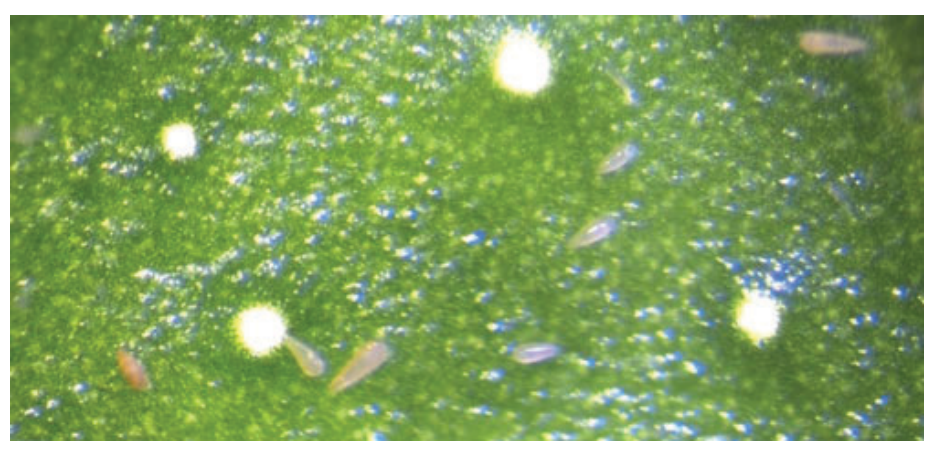

Figure 1. Adults and immatures of the citrus rust mite, Phyllocoptruta oleivora (Ashmead), on a citrus leaf.

Credits: Emilie Demard, UF/IFAS

\section{Description and Identification}

Phyllocoptruta oleivora adults are very small (about 0.15 $\mathrm{mm}$ long), and similar in size to Aculops pelekassi (Vacante 2010). Color ranges from light yellow to straw in Phyllocoptruta oleivora and from pink to reddish in Aculops pelekassi (Villanueva 2002, Futch et al. 2017, Qureshi and Stansly 2019). It is difficult to observe and differentiate these two species with the naked eye. It is not uncommon to misidentify one for the other based on appearance; however, they can be differentiated by several morphological characteristics. While Aculops pelekassi has a convex opisthosoma (abdomen of arachnids), Phyllocoptruta oleivora has a concave opisthosoma (Figure 2, arrow 1A, B). The prodorsal shield (plate on the anterior dorsal surface) of Phyllocoptruta oleivora bears short setae (hair-like structures). On the other hand, the setae of Aculops pelekassi

1. This document is EENY-748, one of a series of the Entomology and Nematology Department, UF/IFAS Extension. Original publication date February 2020. Visit the EDIS website at https://edis.ifas.ufl.edu for the currently supported version of this publication.

2. Emilie Demard, UF/IFAS Indian River Research and Education Center; and Jawwad A. Qureshi, assistant professor, Southwest REC; UF/IFAS Extension, Gainesville, FL 32611.

The Institute of Food and Agricultural Sciences (IFAS) is an Equal Opportunity Institution authorized to provide research, educational information and other services

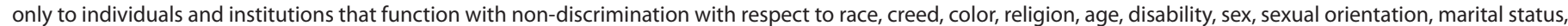

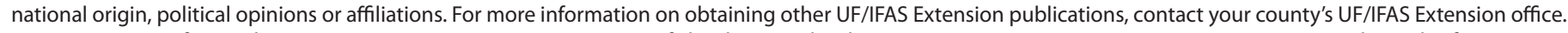
U.S. Department of Agriculture, UF/IFAS Extension Service, University of Florida, IFAS, Florida A \& M University Cooperative Extension Program, and Boards of County Commissioners Cooperating. Nick T. Place, dean for UF/IFAS Extension. 
extend beyond the distal margin of the shield (Childers and Achor 1999) (Figure 2, arrow 2A, B).

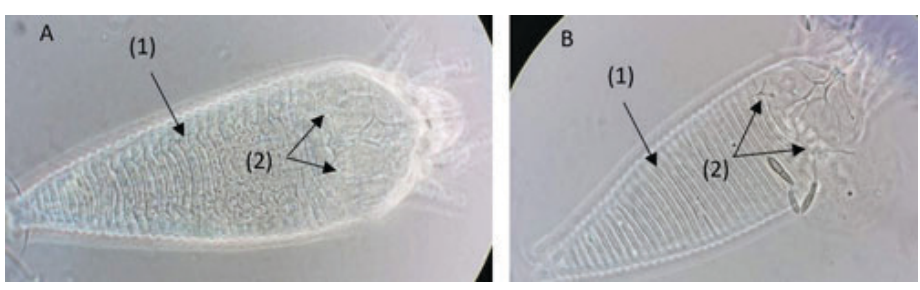

Figure 2. Morphological differences between the citrus rust mite, Phyllocoptruta oleivora (Ashmead) (A), and the pink citrus rust mite, Aculops pelekassi (Keifer) (B), observed with a phase-contrast microscope.

Credits: Emilie Demard, UF/IFAS

\section{Eggs}

Eggs of Phyllocoptruta oleivora are spherical, whereas eggs of Aculops pelekassi are flattened. Egg color varies from transparent to pale translucent yellow. The eggs are about 0.03 to $0.04 \mathrm{~mm}$ (one-fourth the size of the adult mite) (Knapp 1994).

\section{Nymphs}

These mites go through two nymphal instars that look like the adult but are smaller in size (Knapp 1994, Qureshi and Stansly 2019).

\section{Adult}

The adult's body is elongated, wedge-shaped, and about 0.13 to $0.15 \mathrm{~mm}$ in length, with color ranging from light yellow to straw. The mite bears two pairs of short, anterior legs and a pair of lobes on the posterior end that help in clinging to plant surfaces (Figure 3). The opisthosoma (abdomen of arachnids) presents distinct dorsal furrows and bears about 30 dorsal and 60 ventral rings (Knapp 1994, Vacante 2010).

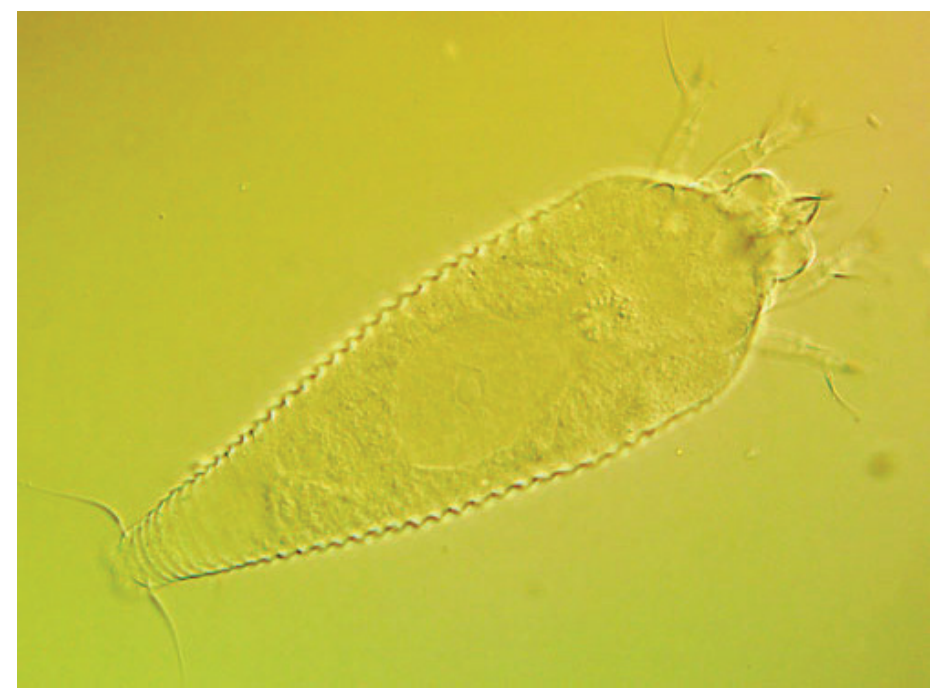

Figure 3. Dorsal view of the citrus rust mite, Phyllocoptruta oleivora (Ashmead).

Credits: Emilie Demard, UF/IFAS

\section{Life History}

Male mites indirectly fertilize female mites. The male deposits spermatophores (protein capsules containing a mass of spermatozoa) on the leaves, and the spermatophores are later taken up by the female. Females start to deposit eggs within one to two days after reaching maturity and can lay up to 30 eggs throughout their lifespan of 20 days. The eggs are laid singly or in groups on the underside of the leaves and on the fruit surface. The species is arrhenotokous; fertilized eggs develop into females and unfertilized eggs into males. Phyllocoptruta oleivora undergoes four development stages during its life cycle: egg, first nymphal stage, second nymphal stage, and adult (Qureshi and Stansly 2019). Immature mites undergo two molts, and each nymphal stage lasts one to three days. The life cycle is completed in 10 days during summer and 14 days during winter. The optimum conditions for the development of Phyllocoptruta oleivora are temperatures between 30 to $32^{\circ} \mathrm{C}$ and high relative humidity (Dean 1959, Ebrahim 2000). Up to 30 generations are possible in one year (Knapp 1994, Vacante and Gerson 2012).

In Florida, populations of Phyllocoptruta oleivora first appear on leaves in spring and begin to increase in late April to early May on new foliage, reaching a peak between mid-June to mid-July. When young fruits develop, the mites move to them. Phyllocoptruta oleivora numbers usually decline in late August and increase again in fall (late October or early November) but at lower levels than those observed during summer (Knapp 1994, Hoy 2011, Qureshi and Stansly 2019). During the summer, Phyllocoptruta oleivora is more abundant on fruits and foliage on the outer margins of the canopy. Phyllocoptruta oleivora does not tolerate full shade nor direct sunlight, so the north bottom quadrant of the tree is often preferred (Allen and McCoy 1979, Qureshi and Stansly 2019).

\section{Damage}

Phyllocoptruta oleivora infests mature branches, green twigs, leaves, and fruits of commercial citrus, causing significant yield losses (Knapp 1994; Vacante and Gerson 2012). The most damage is done on the fruit skin, which reduces the quality and rating of the fresh-market fruits. As high aesthetic standards are required for fresh-market fruit, only lower mite densities are tolerated compared to higher densities acceptable on fruits grown for juice. Thus, Florida citrus groves producing fruits for the fresh market may receive more sprays of miticides averaging three or four per year, typically between April to October, while groves 
producing fruits for processing receive zero to two sprays per year (Qureshi and Stansly 2019).

Depending on the variety and age of fruit, injuries caused on the fruits may differ. When the epidermal cells are destroyed early in the season before fruit mature, damage to the peel is called russeting. This type of damage reduces the size of the fruit and produces cracks that give the fruit a rough texture and a brown-black color (Figure 4). The destruction to the epidermal cells continue to increase resulting in fractures as the fruit enlarges. These symptoms are called sharkskin. Damage is referred to as bronzing when a mature fruit maintains intact epidermal cells and wax layer, giving a polished look (McCoy 1996a; Hoy 2011; Futch et al. 2012; Qureshi and Stansly 2019).

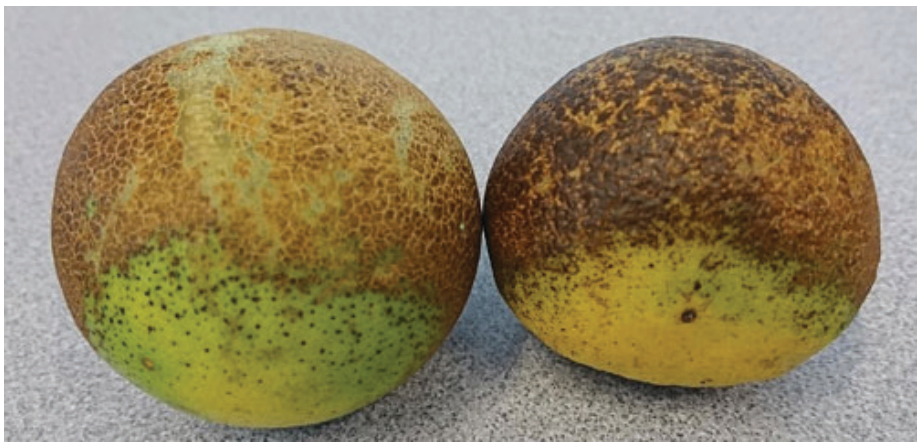

Figure 4. Russeting damage induced by Phyllocoptruta oleivora (Ashmead), on grapefruit.

Credits: Emilie Demard, UF/IFAS

Beside reduction in fruit grade and size, the damage from mite feeding leads to reduced juice quality, increased water loss, and premature fruit drop (Yothers and Mason 1930; McCoy and Albrigo 1975; Allen et al. 1994). The increased water loss from fruits may increase their brix content (concentration of total soluble solids) (Gonzalez et al. 1983; Knapp 1994). Nevertheless, as the percentage of acids also increase, the brix/acid ratio remains the same (Knapp 1994). Furthermore, high concentrations of acetaldehydes and ethanol have been associated with off-flavor juice of affected fruits (McCoy et al. 1976; Knapp 1994).

Injury to leaves occurs on the upper and lower surfaces. The upper leaf surface takes on a bronze-like color and/ or shows patchiness of yellowish cells, while the lower leaf surface shows mesophyll collapse (McCoy 1996a; Hoy 2011; Qureshi and Stansly 2019). Infested twigs may display black spots, and heavy damage can lead to leaf defoliation (Vacante and Gerson 2012).

\section{Host Plants}

Phyllocoptruta oleivora is found on all varieties of citrus (Rutaceae). It also feeds on other rutaceous hosts such as tabog, Swinglea glutinosa (Blanco) Merr, and kumquats, Fortunella spp. (Vacante and Gerson 2012).

\section{Survey and Detection}

Three general approaches are mainly used: 1 ) the percentage infestation of fruits and/or leaves 2) qualitative rating scales to estimate mite density (low, medium, high) and 3 ) individual adult mite counts. Although the first two methods are rapid, they are insensitive to seasonal variation in mite population density. Individual counts are the most accurate and common but time consuming and impractical when sampling in large areas needs to be done (Rogers et al. 1994, Aghajanzaseh and Malik 2007; Hall et al. 2007). As an alternative, Rogers et al. (1994) used a modified Horsfall-Barratt system to estimate population densities of Phyllocoptruta oleivora with a $10 \times$ hand lens (Figure 5). Hall et al. (2007) also investigated binomial sampling based on the proportion of samples infested to estimate the mite densities.
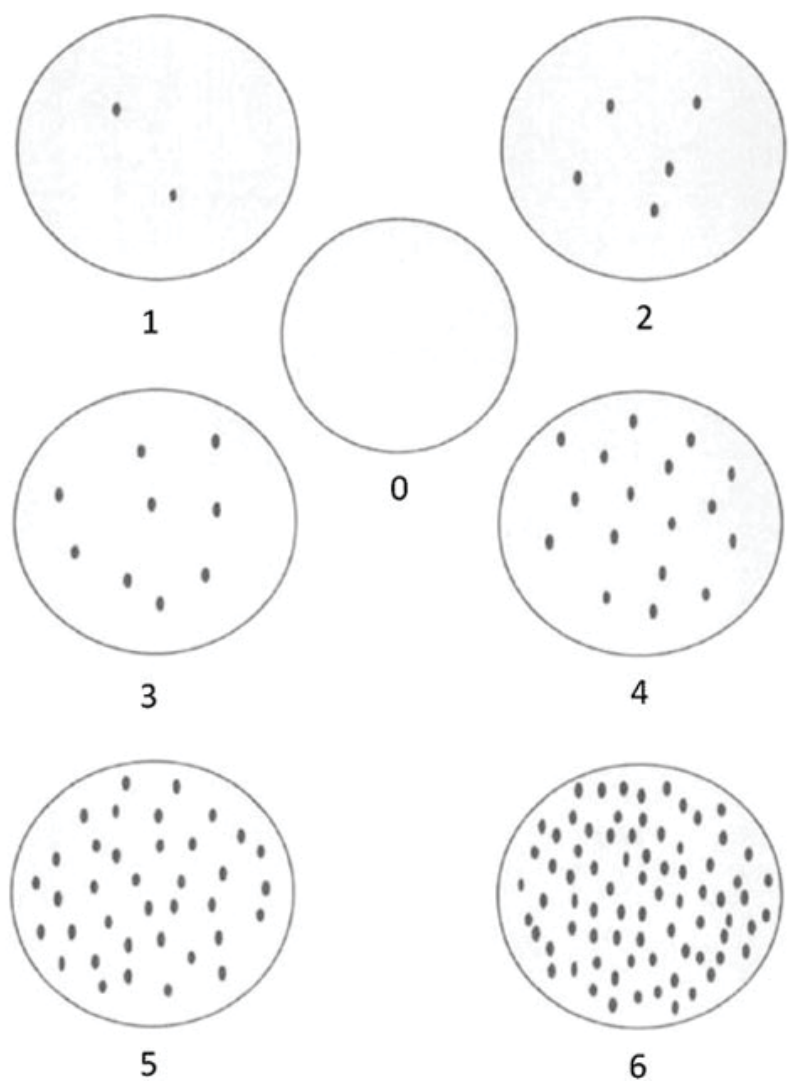

Figure 5. Standardized visual comparison key to quantify densities of Phyllocoptruta oleivora (Ashmead). The circles represent a view of the leaf surface with a 10x hand lens. The small black spots represent Phyllocoptruta oleivora. The coded values are based on the HorsfallBarratt system.

Credits: Rogers et al. (1994) 
It is suggested to sample a 10-to-40-acre block by checking 20 trees at random (Qureshi and Stansly 2019). One fruit, located midway in the canopy, is chosen from each of the four quadrants of the trees. The number of rust mites per square centimeter is recorded. Phyllocoptruta oleivora has a rapid growth capacity and a short generation time during summer. Therefore, it is important to monitor the populations every 2 to 3 weeks once detected and plan spray treatments following a threshold of $2 \mathrm{mites} / \mathrm{cm}^{2}$ for fresh fruit and 6-10 mites $/ \mathrm{cm}^{2}$ for processed fruit (Qureshi and Stansly 2019).

\section{Management \\ Biological Control}

Predatory mites in the families Stigmaeidae and Phytoseiidae are the most significant predators of Phyllocoptruta oleivora, but only a few species are reported to feed on the pest mites. The small size and low nutritional value of Phyllocoptruta oleivora are likely reasons that they are overlooked by predatory mites compared with larger prey, such as spider mites (Childers 1994a, Villanueva 2002).

In Florida citrus, three indigenous predatory mite species in family Phytoseiidae that prey on spider mites have been studied as potential biological agents of eriophyoid mites: Euseius mesembrinus (Dean); Iphiseiodes quadripilis (Banks); and Typhlodromalus peregrinus (Muma) (Villanueva and Childers 2004).

Typhlodromalus peregrinus (Figure 6) is the only species observed to feed on Phyllocoptruta oleivora, although it prefers the broad mite, Polyphagotarsonemus latus (Banks) when it is present (Peña 1992). Agistemus floridanus Gonzalez, a commonly encountered stigmaeid mite in Florida citrus groves, is recorded to feed and reproduce on Phyllocoptruta oleivora (Muma and Selhime 1971). Villanueva et al. (2006) demonstrated that two undescribed species of Cecidomyiidae, one identified as Feltiella n. sp. and the other near the genus Lestodiplosis, prey upon Phyllocoptruta oleivora.

The entomopathogenic fungus Hirsutella thompsonii Fisher infects Phyllocoptruta oleivora (McCoy 1996b). In Florida citrus groves, outbreaks of the fungus last three to four weeks and sufficient inoculum remains in the environment to suppress mite populations for several months (Chandler et al. 2000). The use of fungicides, such as copper, to control fungal pathogens of citrus, kill the enthomopathogenic fungus, which limits its effectivness for biological control. Beauvaria bassiana (Bals.-Criv.) Vuill. is also known to attack Phyllocoptruta oleivora in laboratory studies; however, its efficacy in the field has not been demonstrated yet (Alves et al. 2005).

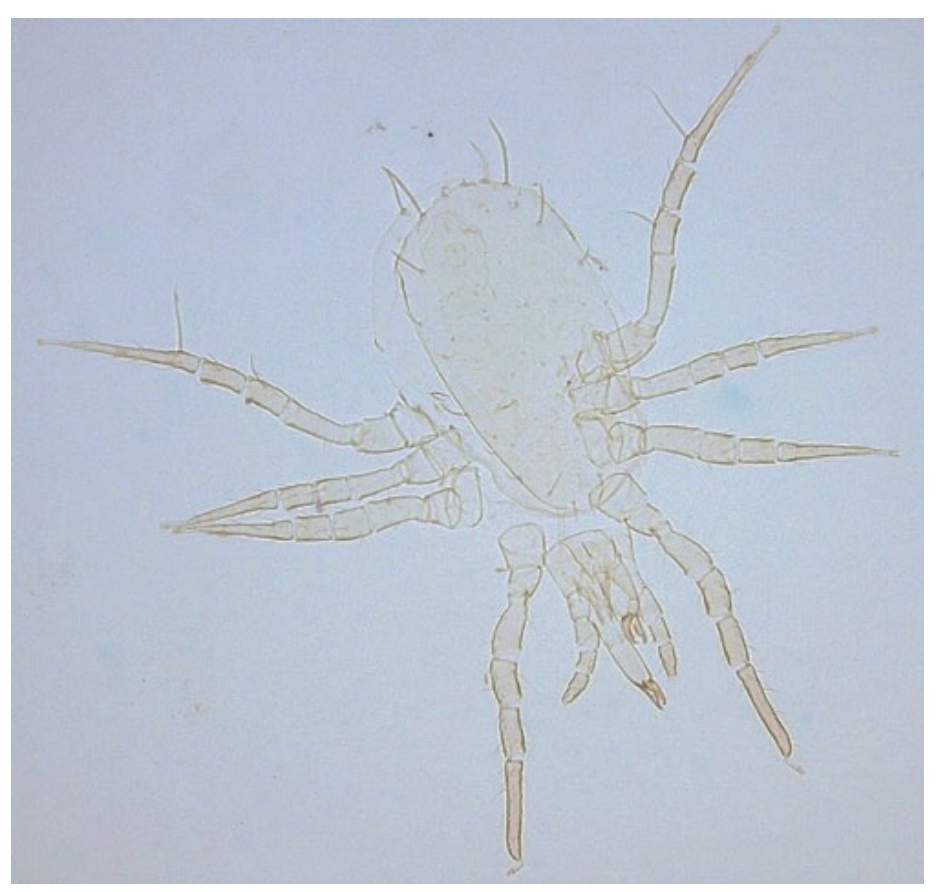

Figure 6. Adult female Typhlodromalus peregrinus (Muma), a predatory mite that feeds on Phyllocoptruta oleivora (Ashmead), observed with a phase contrast microscope.

Credits: Emilie Demard, UF/IFAS

\section{Chemical Control}

Chemical control is the primary method used to manage Phyllocoptruta oleivora. Acaricides currently allowed for use in citrus are listed in the citrus production guide chapter on mites: http://edis.ifas.ufl.edu/cg002 (Qureshi and Stansly 2019). Mite resistance to chemicals is a serious concern and reported against zineb (Herne et al. 1979), diflubenzuron (Knapp et al. 1988), dicofol (Omoto et al. 1994), and fenbutin oxide (Childers 1994b). No miticide should be applied more than once per season to avoid development of mite resistance. Chemical control also negatively impacts natural enemies, which can induce Phyllocoptruta oleivora resurgence and flare populations of secondary pests (Villanueva 2002). Sprays of different types of oils are an important component of integrated citrus pest management and relatively less damaging to biological control agents. These provide good insect and mite pest control but may need to be applied more frequently because their residual effects are less compared with conventional products (Qureshi and Stansly 2019). Moreover, oils require careful use to reduce the likelihood of phytotoxicity, specifically during hot and dried seasons (Hoy 2011). Wettable sulfur applications represent an alternative to conventional acaricides but their use should be minimized due to their toxicity to beneficial arthropods such as phytoseiid mites (Qureshi and Stansly 2019). 


\section{References}

Aghajanzadeh S, Mallik B. 2007. Sampling and distribution pattern of citrus rust mite, Phyllocoptruta oleivora Ashmead (Acari, Eriophyidae) using adhesive tape method. International Journal of Agriculture and Biology 9: 329-332.

Allen JC, McCoy CW. 1979. The thermal environment of the citrus rust mite. Agricultural Meteorology 20: 411-425.

Allen JC, Yang Y, Knapp JL, Stansly PA. 1994. The citrus rust mite story: a modeling approach to a fruit-mite-pathogen system, pp. 619-639. In: Rosen D, Bennett F, Capinera J (eds.). Pest Management in the Subtropics: Biological Control- a Florida Perspective. Intercept, Andover, UK.

Alves SB, Tamai MA, Rossi LS, Castiglioni E. 2005. Beauveria bassiana pathogenicity to the citrus rust mite Phyllocoptruta oleivora. Experimental and Applied Acarology 37: 117-122.

Burditt AK, Reed DK, Crittenden CR. 1963. Observations on the mites Phyllocoptruta oleivora (Ashmead) and Aculus pelekassi Keifer under laboratory conditions. Florida Entomologist 46: 1-5.

Chandler, D, Davidson G, Pell JK, Ball BV, Shaw K, Sunderland KD. 2000. Fungal biocontrol of Acari. Biocontrol Science and Technology 10: 357-384.

Childers CC. 1994a. Biological control of phytophagous mites on Florida citrus utilizing predatory arthropods, pp. 255-288. In: Rosen D, Bennet FD, and Capinera JL eds. Pest Management in the Subtropics. Intercept, Andover, UK.

Childers CC. 1994b. Effect of different copper formulations tank mixed with fenbutatin-oxide for control of citrus rust mite (Acari Eriophyidae) on Florida citrus. Florida Entomologist 77: 349-365.

Childers CC, Achor DS. 1999. The eriophyoid mite complex on Florida citrus (Acari: Eriophyidae and Diptilomiopidae). Proceedings of the Florida State Horticultural Society 112: 79-87.

CIE. 1970. Distribution Maps of Plant Pests, No. 78. Wallingford, UK: CAB International.

Dean HA. 1959. Seasonal distribution of mites on Texas grapefruit. Journal of Economic Entomology 52: 228-232.
Ebrahim HM. 2000. Influence of temperature and relative humidity on the biology and life table parameters of Phyllocoptruta oleivora and Aculops pelekassi (Acari: Eriophyidae) on "Hamlin" orange in Central Florida. Egyptian Journal of Agricultural Research 78: 143-161.

Futch SH, Childers CC, McCoy CW. 2017. A Guide to Citrus Mite Identification. HS-806. https://edis.ifas.ufl.edu/ ch179. Accessed 27 Aug 2019.

Gonzalez N, Kalinin V, Diaz E. 1983. Dinámica poblacional del ácaro d elmoho durante cuatro años, relacionada con la fenologÃa de naranja Valencia. Ciencia y Técnica en la Agricultura, Protección de Plantas 6: 35-62.

Hall DG, Childers CC, Eger JE. 2007. Binomial sampling to estimate rust mite (Acari: Eriophyidae) densities on orange fruit. Journal of Economic Entomology 100: 233-240.

Herne DHC, Cranham JE, Easterbrook MA. 1979. New acaricides to control resistant mites. In: J.G. Rodriguez (Editor), Recent advances in acarology, Vol. 1. Academic Press, New York, USA, pp. 95-104.

Hoy MA. 2011. Agricultural Acarology: Introduction to Integrated Mite Management. CRC Press, Boca Raton, Florida, 430.

Knapp JL. 1994. Citrus Rust Mite. ENY619. Gainesville: University of Florida Institute of Food and Agricultural Sciences.

Knapp JL, Anderson HA, Appelboom TW. 1988. Orange citrus rust mite control. Insecticide and Acaricide Tests 13: 79-80.

McCoy CW. 1996a. Stylar feeding injury and control of eriophyoid mites in citrus, pp. 513-526. In: Lindquist EE, Sabelis MW, and Bruin J eds. Eriophyoid Mites: Their Biology, Natural Enemies and Control, vol. 6. Elsevier Science, Amsterdam, The Netherlands.

McCoy CW. 1996b. Pathogens of eriophyoid mites, pp 481-490. In: Lindquist EE, Sabelis MW, and Bruin J eds. Eriophyoid Mites: Their Biology, Natural Enemies and Control, vol. 6. Elsevier Science, Amsterdam, The Netherlands.

McCoy CW, Albrigo LG. 1975. Feeding injury to the orange caused by the citrus rust mite, Phyllocoptruta oleivora (Prostigmata: Eriophyoidea). Annals of the Entomological Society of America 68: 289-297. 
McCoy CW, Davis, PL, Munroe KA. 1976. Effect of late season fruit injury by the citrus rust mite, (Prostigmata: Eriophyoidea), on the internal quality of Valencia orange. Florida Entomologist 59, 335-342.

Muma MH, Selhime AG. 1971. Agistemus floridanus (Acarina: Stigmaeidae), a predatory mite, on Florida citrus. Florida Entomologist 54: 249-258.

Omoto C, Dennehy TJ, McCoy CW, Crane SE, Long JW. 1994. Detection and characterization of the interpopulation variation of citrus rust mite resistance to dicofol in Florida citrus. Journal of Economic Entomology 84: 566-572.

Peña JE. 1992. Predator-prey interactions between Typhlodromalus peregrinus and Polyphagotarsonemus latus: Effects of alternative prey and other food resources. Florida Entomologist 75: 241-248.

Qureshi JA, Stansly PA. 2019. Rust Mites, Spider Mites, and Other Phytophagous Mites. ENY-603. Gainesville: University of Florida Institute of Food and Agricultural Sciences. https://edis.ifas.ufl.edu/cg002. Accessed 8 Nov 2019.

Rogers JS, McCoy CW, Manners MM. 1994. Standardized visual comparison keys for rapid estimation of citrus rust mite population. Journal of Economic Entomology 87: 1-6.

Tropea Garzia G, De Lillo E. 2018. Geographic distribution of Phyllocoptruta oleivora in the Mediterranean Basin, with particular emphasis on Italy. Systematic and Applied Acarology 23: 1021-1023.

Vacante V. 2010. Citrus Mites: Identification, Bionomy, and Control. CABI International. Wallingford, UK.

Vacante V, Gerson U. 2012. Acari, pp. 88-108. In: Vacante $\mathrm{V}$, and Gerson U. Integrated control of citrus pests in the Mediterranean region. Bentham Science Publishers, Sharjah, UAE.

Villanueva RT. 2002. A study of the biology and ecology of selected predators of phytophagous mites on Florida citrus. Doctoral dissertation. University of Florida, Gainesville.

Villanueva RT, Childers CC. 2004. Diurnal and spatial patterns of Phytoseiidae in the citrus canopy. Experimental and Applied Acarology 35: 269-280.
Villanueva RT, GagnÃ@) R, Childers CC. 2006. Two species of cecidomyiidae predacious on citrus rust mite, Phyllocoptruta oleivora, on Florida citrus. Florida Entomologist 89: 161-167.

Yothers WW, Mason AC. 1930. The citrus rust mite and its control. USDA Technical Bulletin 176. 